\title{
Therapeutic management of intestinal fibrosis induced by radiation therapy: from molecular profiling to new intervention strategies et vice et versa
}

\author{
Saad Hamama ${ }^{1,2}$, Sylvie Delanian ${ }^{1,2,3}$, Virginie Monceau', Marie-Catherine Vozenin ${ }^{1,2^{*}}$ \\ From Fibroproliferative disorders: from biochemical analysis to targeted therapies \\ Frauenchiemsee, Germany. 25-30 September 2010
}

\begin{abstract}
Chronic toxicities of locoregional and systemic oncological treatments commonly develop in long-term cancer survivors. Amongst these toxicities, post-radiotherapeutic complications alter patient's quality of life. Reduction of exposure of normal tissues can be achieved by optimization of radiotherapy. Furthermore, understanding of the fibrogenic mechanisms has provided targets to prevent, mitigate, and reverse late radiation-induced damages. This mini-review shows how (i) global molecular studies using gene profiling can provide tools to develop new intervention strategies and (ii) how successful clinical trials, conducted in particular with combined pentoxifyllinevitamin $E$, can take benefice of biological and molecular evidences to improve our understanding of fibrogenic mechanisms, enhance the robustness of proposed treatments, and lead ultimately to better treatments for patient's benefice.
\end{abstract}

\section{Introduction}

Therapeutic management of cancer improved during the past decade and is characterized today by a significant increase in patient's survival rates. Although effective on cure rates, both locoregional and systemic oncological treatments present some concerns related to development of chronic toxicities that alter patient's quality of life, while results of combined therapies suggest that normal tissue toxicity will become a major concern within the next years. Amongst these toxicities, radiation enteropathy is a significant delayed side effect of lumbar and pelvic radiotherapy.

The risk, severity and nature of these radiation-induced toxicities depend on several factors including radiotherapy-related factors (total dose, dose per fraction and volume exposure) and patient-related factors (comorbidities) [1]. Accordingly, a real effort has been made to

\footnotetext{
* Correspondence: vozenin@igr.fr

'INSERM U-1030 "Molecular Radiotherapy" Institut Gustave Roussy, Villejuif, France

Full list of author information is available at the end of the article
}

reduce normal tissue exposure by ballistic and imaging optimization of radiotherapy. Besides technological tools, understanding the fibrogenic mechanisms and targeting profibrotic factors has provided alternate and promising approaches to prevent, mitigate or even reverse late radiation-induced damages $[1,2]$.

If today's clinical practice always aims to limit aggravating factors, current management of radiation-induced damages involves [3]: (i) anti-inflammatory treatments including corticosteroids; (ii) vascular therapy including pentoxifylline (PTX) or hyperbaric oxygen; (iii) antioxidant treatment including superoxide dismutase in the nineties and then combined pentoxifylline-vitamin $\mathrm{E}$ (PTX-VitE) in the last decade.

The first part of this mini-review shows how global molecular studies using gene profiling can provide tools to develop new intervention strategies with old molecules or new compounds. The second part shows how successful clinical research done with well-known but low potent old drugs takes benefice of biological and molecular evidences to improve its robustness for patient's benefice. 


\section{From molecular profiling to new intervention strategies \\ Cellular and molecular mechanisms involved in the persistence of radiation fibrosis}

In all irradiated tissues and especially when vital organs like the heart, lung or intestine are affected [4], the most concerning aspect of radiation fibrosis is its progressive and seemingly irreversible evolution. Thus, the development of curative anti-fibrotic strategies is nowadays highly anticipated by both patients and physicians [5]. Definition of new biologically-based anti-fibrotic strategies is therefore an attractive option to be achieved by characterization of the cellular and molecular mechanisms involved in the persistence of radiation fibrosis.

In human radiation enteropathy, fibrosis is the main histopathological hallmark [6]. Fibrosis contributes to the loss of intestinal compliance and impaired intestinal function and we showed that it was associated with heavy deposition of Connective Tissue Growth Factor (CTGF/ CCN2) [7]. CTGF gene regulation is known to be under the control of TGF- $\beta$ via a Smad consensus sequence and TGF- $\beta$ RE/BCE- 1 binding sites located in the CTGF promoter region $[8,9]$. We showed that, surprisingly, TGF- $\beta 1$ expression in fibrotic area was low during the onset of radiation enteropathy [7]. The molecular basis of this paradox was investigated using (i) a high-throughput biological approach by cDNA array profiling and (ii) a classical biochemical approach with recombinant TGF- $\beta 1$ and CTGF. These studies were performed with unique and physiologically relevant cell models, employing primary smooth muscle cells and sub-epithelial myofibroblasts derived from radiation enteropathy. These cells mimic fibrosis in vitro, as they maintain their fibrogenic features in long term culture (6-8 passages) i.e. altered contractile function, modification of the actin cytoskeleton and increased secretory activity $[10,11]$.

The comprehensive cDNA approach showed activation of the Rho/ROCK pathway [12]. Further functional in vitro experiments showed that this intercellular signaling pathway controls CTGF expression in intestinal smooth muscle cells and in subepithelial myofibroblasts derived from radiation enteropathy $[10,13]$. In addition, our gene profiling studies showed that radiation enteropathy was associated with a global deregulation of the extracellular matrix remodeling with increased ECM deposition, MMPs and TIMPs activity [14]. Whether this dynamic remodeling process was the cause or the consequence of the phenotypic alteration of the resident mesenchymal cells is currently under investigation.

Cell response to increasing concentrations of recombinant TGF- $\beta 1$ was investigated. Activation of cell-specific signaling pathways by low TGF- $\beta 1$ concentrations was demonstrated with a prominent activation of the Rho/
ROCK pathway in fibrosis-derived cells, whereas the Smad pathway was predominantly activated in normal cells. This differential fibrogenic response identified in normal versus fibrosis-derived cells opened new therapeutic opportunities for targeted anti-fibrotic therapy. In addition, we showed that recombinant CTGF was able to trigger its auto-induction in fibrosis-derived cells, an effect which was further enhanced by TGF- $\beta 1$. These results thus identify specific and combinatorial roles of low TGF- $\beta 1$ doses and CTGF for the maintenance of tissue fibrosis [15].

\section{From physiopathological mechanisms to clinical transfer}

Rho GTPases regulate fundamental cellular processes including cell motility, cell cycle progression, cell survival, transcription, membrane trafficking and cytokinesis via their downstream effectors the Rho-associated kinases (ROCKs) [16,17]. Many Rho functions have been elucidated using pharmacological inhibitors, the most prominent ones being Statins, molecules which inhibit isoprenoid intermediates production and Rho activation. In order to investigate whether the Rho/ ROCK cascade regulates radiation-induced fibrogenic program in intestinal mesenchymal cells, pharmacological inhibition of Rho and ROCK activation was performed in vitro using pravastatin and Y-27632, a pyrimidine derivative inhibitor of ROCK. We showed that both agents modulated radiation-induced fibrogenic differentiation and the expression of CTGF, TGF- $\beta 1$, and collagen I $\alpha 2$ genes (Figure 1), most likely via NF$\kappa \mathrm{B}$ inhibition $[10,11,18]$. Next, therapeutic experiments were conducted in pre-clinical models. Pravastatin was chosen as, in the case of convincing results, it would be easy to accelerate the transfer of this drug to the clinic, given the fact that the drug is safe and well tolerated [19]. Remarkably, we showed that pravastatin administration with curative intent improves radiation enteropathy in rats, inhibits Rho and ROCK activity in human samples, and subsequently inhibits CTGF production in-vivo, ex-vivo, and in-vitro. In addition, inhibition of type-I-collagen and fibronectin occurred, indicating that pravastatin modulates the secretory phenotype of mesenchymal cells, probably by inhibition of the Rho/ROCK/CTGF/ ECM cascade [13]. Mitigation experiments with pravastatin, relevant to clinically well-established fibrosis, improved delayed radiation enteropathy in rats and decreased both CTGF expression and collagen deposition. Interestingly, pravastatin's protective effect was differential, as no tumor protection occurred [20]. Similar results were obtained by others using Simvastatin [21] and anti-fibrotic efficacy of statins was shown in model of radiation-induced lung [22,23]. These pre-clinical findings encouraged us to propose a phase II randomized clinical trial, which received approval from the local 

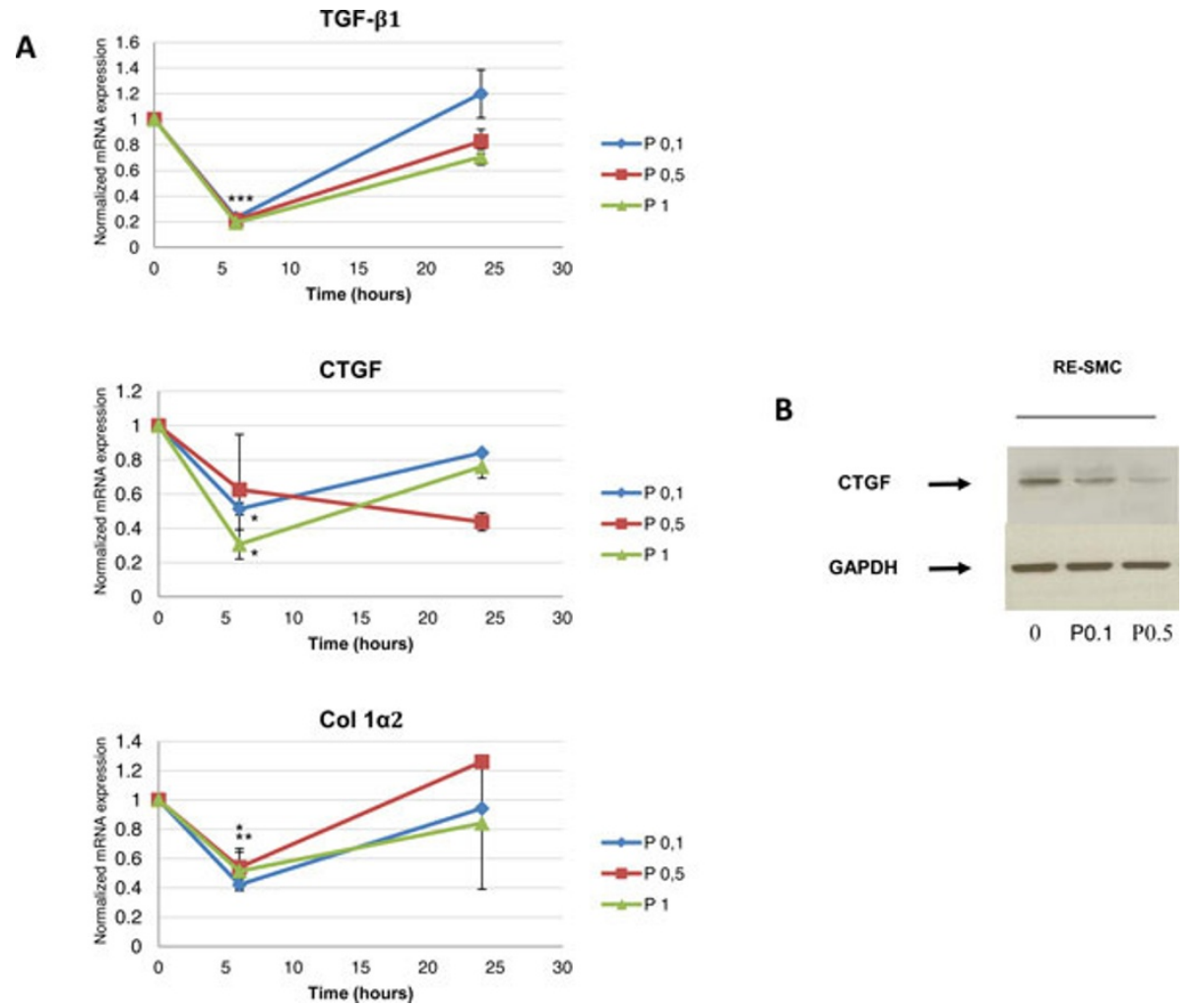

Figure 1 A. Effect of Pravastatin on mRNA expression of TGF $\beta 1$, CTGF and Collagen in a kinetic manner: Twenty four hours kinetics of mRNA expression of TGF $\beta 1, C T G F$, and Col l $\alpha 2$ in control and Pravastatin treated cells show that Pravastatin treatment with a dose of $0.1 \mathrm{mM}$ and up reduces levels of mRNAs of these genes with maximum efficiency at six hours post-treatment; C: control, P: Pravastatin treatment. 0.1, 0.5 , and 1 refer to treatment dose in $\mathrm{mM}^{*}: \mathrm{p}<0.05,{ }^{* *}: \mathrm{p}<0.01,{ }^{* * *}: \mathrm{p}<0.005$ according to kruskal-Wallis test. B. Protein expression of CTGF in control and Pravastatin treated cells: Pravastatin treatment for 24 hours inhibits CTGF protein expression showing also a dose-response relationship. GAPDH is used as a housekeeping gene. C: control, P: Pravastatin treatment. $0.1,0.5$ refer to treatment dose in mM.

ethics committee and started at Institut Gustave Roussy in January 2010 with the support of the French Ministry of Health (PHRC 2010).

Searching for anti-fibrotic treatment using molecular targets lead to the development of targeted drugs. Amongst them anti-CTGF antibody [24], imatinib (anti-PDGF antibody) [25-27], statin (Rho/Rock-inhibitors) [20-23,28] have demonstrated efficacy in pre-clinical studies and need now to be validated in clinical trials. Two targeted drugs have recently showed interesting results in recent trials: the small molecule inhibitor of TGF- $\beta 1$, pirfenidone, and the tyrosine kinase inhibitor, BIBF 1120 . Both of them halt progression of idiopathic pulmonary fibrosis [29,30]. Still others, such as combined pentoxifylline-vitamin $\mathrm{E}$ has a proven clinical efficacy with an unknown mechanism of action [31-38].

\section{From clinical trials to understanding the molecular mechanism}

In the nineties an antioxidant compound, the liposomal $\mathrm{Cu} / \mathrm{Zn}$ superoxide dismutase (SOD), was the first drug to half reduce established radiation fibrosis in patients and experimental models (reviewed in [3]). Biological studies showed that SOD inhibited TGF- $\beta 1$ and TIMPs and lead to a subsequent reversion of the myofibroblastic phenotype in vitro [39,40]. Later, Delanian et al. showed that combined PTX-Vit.E administered to patients, half reduced superficial radiation fibrosis in 6 months [31]. Results were confirmed in a randomized clinical trial [32] and by long-term clinical results (3 years) [33]. A first experimental study using skin fibrosis in pig as model showed that the histopathological recovery after PTX/ VitE treatment was associated with significant reduction of TGF- $\beta 1$ deposition [41]. Since then, numerous clinical trials were successful and showed improvement of osteoradionecrosis [34], superficial fibrosis [36], proctitis/ enteritis [37], pelvic complications [38], uterine fibroatrophy $[35,42]$. Moreover, combined PTX-Vit.E in rat experiment had beneficial effects on radiation-induced myocardial fibrosis and left ventricular function [43]. Recent report using a triple combination PENTOCLO: PTX-VitE and clodronate; a biphosphonate active against macrophages also allows successful healing of severe osteoradionecrosis [44] and reduction of neurological 
symptoms associated with radiation-induced plexopathies [45]. The efficacy of this triple combination is currently validated in a phase III randomized clinical trial that has started at Saint Louis Hospital for radiation-induced plexitis (support by the French Ministry of Health, PHRC 2009). Therefore, understanding the molecular mechanism of PTX-Vit.E combination solicit much interest for better understanding of radiation-induced fibrosis, to improve treatment robustness and will pave the way toward new more efficient treatments.

Vitamin $E$ ( $\alpha$-tocopherol) is an antioxidant drug known to modulate the expression of several genes such as ICAM-1 integrins and PPAR-gamma [46]. $\alpha$-tocopherol was reported to decrease the expression of genes known to be involved in the fibrotic process such as (MMP-1) in human skin fibroblast [47], and IL-1 $\beta$ in THP-1 cells [48]. In mice, D- $\alpha$-tocopherol supplementation decreased collagen mRNA in the liver by $70 \%$ [49]. In type 2 diabetic patients, $\alpha$-tocopherol supplementation lowered plasma levels of PAI-1 and P-selectin [50]. In other case, $\alpha$-tocopherol induces the expression of CTGF in human smooth muscle cells while neither $\beta$-tocopherol nor $\mathrm{N}$-acetylcysteine do [51]. It was suggested that this modulation of CTGF was unique as it was not triggered by structurally related antioxidant molecules, suggesting occurrence of a non-antioxidant mechanism in the transcriptional regulation of several genes.

Pentoxifylline, PTX is a methylxanthine derivative used to treat vascular disease such as intermittent claudication. In vivo, it has been reported to have anti-TNF- $\alpha$ effect, increase erythrocyte flexibility, vasodilate, and inhibit inflammatory reactions. In vitro studies have indicated that PTX has also antioxidant properties [52], inhibits human dermal fibroblast proliferation and extracellular matrix production [53-55] and increases collagenase activity [53]. However, the doses of pentoxifylline required to produce these effects in vitro are high, and reached $1000 \mu \mathrm{g} / \mathrm{ml}$ in some cases [54] rendering in vivo use of PTX unsuitable. In addition, PTX is known as a non-specific phosphodiesterases inhibitor that subsequently increases intracellular levels of cAMP. Like other cAMP elevating agents PTX could activate protein kinase A (PKA) which would phosphorylate transcription factors, such as cAMP response element binding protein (CREB). Activated CREB recruits the coactivators CBP and P300 that also act as transcriptional co-activators for SMADs [56,57]. Therefore, the sequestration of CBP/ P300 by activated CREB could inhibit SMAD-dependent transcription [58] and constitute one molecular mechanism to explain PTX anti-fibrotic action that remains to be demonstrated in vivo. For example, in a model RIFinduced in pigs no clinical or histological changes were observed in RIF after 6 months of treatment with PTX alone using maximum tolerated dose [41]. Extrapolation from in vitro studies would however suggest that higher concentration of PTX would be required to achieve effective suppression of collagen synthesis or to increase collagenase activity. Used at this dosage, PTX might be extremely toxic and suggests that administration of PTX alone does not constitute an anti-fibrotic treatment.

Studies about the mechanism of action of combined pentoxifylline-vitamin $\mathrm{E}$ in radiation fibrosis are awfully limited. An in vitro study was conducted in dermal fibroblast using the water-soluble analogue of vitamin E, trolox, to investigate the effects of combined pentoxifylline-trolox on irradiated cells. This study showed reduction in acute and late ROS formation in cells after irradiation, decrease in DNA strand breaks whenever the drugs were added i.e. before or after irradiation supporting an immediate antioxidant action that interfere with the DNA repair process [59]. However, the relevance of this study to fibrosis is unclear since only short term response was investigated, therefore we aimed at investigating the role of combined pentoxifylline-vitamin $\mathrm{E}$ on two well know fibrogenic pathway, i.e. TGF- $\beta 1$ and Rho/Rock using an in vitro model of radiation-induced fibrosis consisting of primary smooth muscle cells derived from human radiation enteropathy samples (RE-SMC). The hydrophilic analogous of $\alpha$-tocopherol, trolox, was used. Incubation of the cells with combined pentoxifylline-trolox didn't regulate RhoB mRNA expression (Figure 2A) nor influence Actin cytoskeleton in RE-SMC (data not shown) but interestingly negatively modulated TGF- $\beta 1$ mRNA expression at early time point (one hour post-treatment) and subsequently decrease the expression of TGF- $\beta 1$ targets such as PAI-1 both at mRNA and protein levels (twenty four hours post-treatment) (Figure $2 \mathrm{~A}$ and $2 \mathrm{~B}$ ). This suggested that the anti-fibrotic effects of combined pentoxifyllinetrolox could be mediated by inhibition of the TGF- $\beta 1$ pathway. Interestingly, pentoxifylline and trolox appear to enhance the activity of each other; and the effect of the combination was more potent than any of the individual treatments, which is the definition of drugs synergy. Combined pentoxifylline-trolox with a dose of $10 \mu \mathrm{g} / \mathrm{ml}$ decreases protein expression of PAI-1 more effectively than trolox alone $(10 \mu \mathrm{g} / \mathrm{ml})$ or pentoxifylline alone $(10 \mu \mathrm{g} / \mathrm{ml})$ (Figure 2B). Thus, the synergy between the elements of this combination at low concentration could constitute the basis of its efficacy conferring a more appropriate therapeutic window. This study offers for the first time, to our knowledge, a molecular base for rationalization of the clinical use of combined Pentoxifylline-vitamin $E$ in radiation fibrosis. Nevertheless, inhibition of TGF- $\beta 1$ pathway is unlikely to be the sole anti-fibrotic mechanism of action of combined pentoxifylline-trolox and other novel candidates are actually under investigations. 


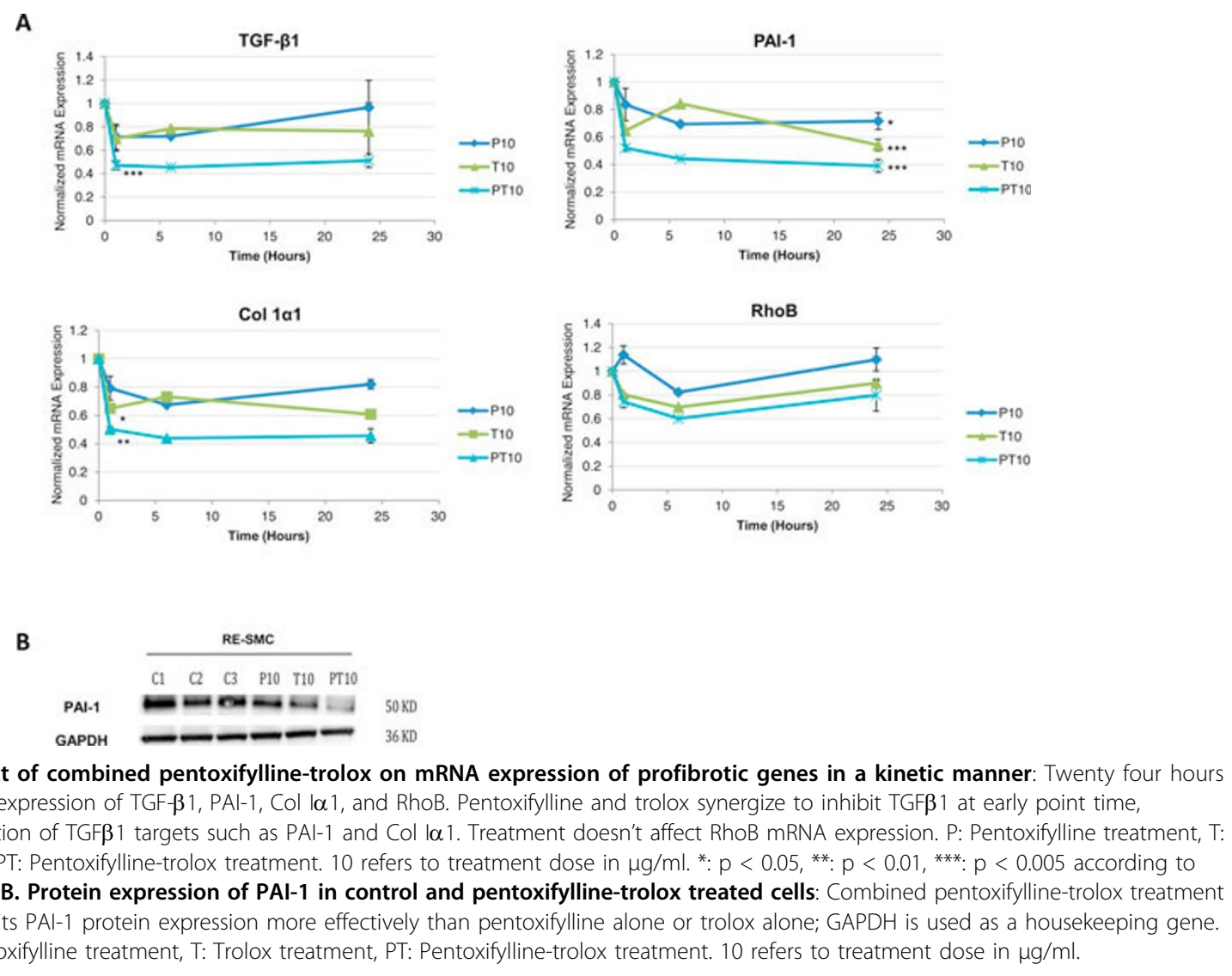

\section{Conclusion}

From molecular profiling to clinical trials in a bottomup manner or from the clinical trials to the molecular understanding in a top-down approach, these studies have optimized our understanding of radiation-induced fibrogenesis. Combining these information could ultimately lead to improve management of fibrosis.

In a model of intestinal fibrosis, Statins act principally via inhibition of Rho/Rock pathway decreasing subsequently the expression of CTGF. In contrast, combined pentoxifylline-trolox inhibits TGF- $\beta 1$ pathway while it appears to have no influence on Rho/Rock pathway. Therefore combining these two medications to generate a more efficient triple therapy seemed a logical follow up. While emerging new combinations might be promising, heavy investigations are needed to prove their safety and efficacy over already solid candidates as Statins or combined pentoxifylline-vitamin $\mathrm{E}$.

\section{Acknowledgements}

This article has been published as part of Fibrogenesis \& Tissue Repair Volume 5 Supplement 1, 2012: Proceedings of Fibroproliferative disorders: from biochemical analysis to targeted therapies. The full contents of the supplement are available online at http://www.fibrogenesis.com/ supplements/5/S1.

\section{Author details}

${ }^{1}$ INSERM U-1030 "Molecular Radiotherapy" Institut Gustave Roussy, Villejuif, France. "Molecular Radiotherapy", Université Paris Sud Paris XI, France.

${ }^{3}$ Unité de Radiopathologie, Service Oncologie-Radiothérapie, Hôpital SaintLouis, APHP, Paris, France.

\section{Competing interests}

The authors declare that they have no competing interests.

Published: 6 June 2012

\section{References}

1. Delanian S, Lefaix $\mathrm{L}$ : The radiation-induced fibroatrophic process: therapeutic perspective via the antioxidant pathway. Radiother Oncol 2004, 73(2):119-131.

2. Gervaz $P$, Morel $P$, Vozenin-Brotons $M C$ : Molecular aspects of intestinal radiation-induced fibrosis. Curr Mol Med 2009, 9(3):273-280.

3. Delanian $\mathrm{S}$, Lefaix $\mathrm{J}$ : Current management for late normal tissue injury: radiation-induced fibrosis and necrosis. Semin Radiat Oncol 2007, 17(2):99-107.

4. Hauer-Jensen M, Wang J, Denham JW: Bowel injury: current and evolving management strategies. Semin Radiat Oncol 2003, 13(3):357-371.

5. Anscher MS: The irreversibility of radiation-induced fibrosis: fact or folklore? J Clin Oncol 2005, 23(34):8551-8552.

6. Fajardo LF: The pathology of ionizing radiation as defined by morphologic patterns. Acta Oncol 2005, 44(1):13-22.

7. Vozenin-Brotons MC, Milliat F, Sabourin JC, de Gouville AC, Francois A, Lasser P, Morice P, Haie-Meder C, Lusinchi A, Antoun S, et al: Fibrogenic signals in patients with radiation enteritis are associated with increased connective tissue growth factor expression. Int J Radiat Oncol Biol Phys 2003, 56(2):561-572. 
8. Grotendorst GR, Okochi H, Hayashi N: A novel transforming growth factor beta response element controls the expression of the connective tissue growth factor gene. Cell Growth Differ 1996, 7(4):469-480.

9. Leask A, Holmes A, Black CM, Abraham DJ: Connective tissue growth factor gene regulation. Requirements for its induction by transforming growth factor-beta 2 in fibroblasts. J Biol Chem 2003, 278(15):13008-13015.

10. Bourgier C, Haydont V, Milliat F, Francois A, Holler V, Lasser P, Bourhis J, Mathe D, Vozenin-Brotons MC: Inhibition of Rho kinase modulates radiation induced fibrogenic phenotype in intestinal smooth muscle cells through alteration of the cytoskeleton and connective tissue growth factor expression. Gut 2005, 54(3):336-343.

11. Haydont V, Mathe D, Bourgier C, Abdelali J, Aigueperse J, Bourhis J, Vozenin-Brotons MC: Induction of CTGF by TGF-beta1 in normal and radiation enteritis human smooth muscle cells: Smad/Rho balance and therapeutic perspectives. Radiother Oncol 2005, 76(2):219-225.

12. Vozenin-Brotons MC, Milliat F, Linard C, Strup C, Francois A, Sabourin JC, Lasser $P$, Lusinchi $A$, Deutsch $E$, Girinsky $T$, et al: Gene expression profile in human late radiation enteritis obtained by high-density CDNA array hybridization. Radiat Res 2004, 161(3):299-311.

13. Haydont V, Bourgier C, Vozenin-Brotons MC: Rho/ROCK pathway as a molecular target for modulation of intestinal radiation-induced toxicity. Br J Radiol 2007, 80(Spec No 1):S32-40.

14. Strup-Perrot C, Mathe D, Linard C, Violot D, Milliat F, Francois A, Bourhis J, Vozenin-Brotons MC: Global gene expression profiles reveal an increase in mRNA levels of collagens, MMPs, and TIMPs in late radiation enteritis. Am J Physiol Gastrointest Liver Physiol 2004, 287(4):G875-885.

15. Haydont V, Riser BL, Aigueperse J, Vozenin-Brotons MC: Specific signals involved in the long-term maintenance of radiation-induced fibrogenic differentiation: a role for CCN2 and low concentration of TGF-beta1. Am J Physiol Cell Physiol 2008, 294(6):C1332-1341.

16. Ridley AJ: Rho GTPases and cell migration. J Cell Sci 2001, 114(Pt 15):2713-2722.

17. Vieu $\mathrm{E}$, Hernandez $\mathrm{N}$ : Actin's latest act: polymerizing to facilitate transcription? Nat Cell Biol 2006, 8(7):650-651.

18. Boerma M, Fu Q, Wang J, Loose DS, Bartolozzi A, Ellis JL, McGonigle S, Paradise $E$, Sweetnam P, Fink LM, et al: Comparative gene expression profiling in three primary human cell lines after treatment with a novel inhibitor of Rho kinase or atorvastatin. Blood Coagul Fibrinolysis 2008, 19(7):709-718.

19. Greenwood J, Steinman L, Zamvil SS: Statin therapy and autoimmune disease: from protein prenylation to immunomodulation. $\mathrm{Nat} \mathrm{ReV}$ Immunol 2006, 6(5):358-370.

20. Haydont V, Gilliot O, Rivera S, Bourgier C, Francois A, Aigueperse J, Bourhis J, Vozenin-Brotons MC: Successful mitigation of delayed intestinal radiation injury using pravastatin is not associated with acute injury improvement or tumor protection. Int I Radiat Oncol Biol Phys 2007, 68(5):1471-1482.

21. Wang J, Boerma M, Fu Q, Kulkarni A, Fink LM, Hauer-Jensen M: Simvastatin ameliorates radiation enteropathy development after localized, fractionated irradiation by a protein C-independent mechanism. Int J Radiat Oncol Biol Phys 2007, 68(5):1483-1490

22. Williams JP, Hernady E, Johnston CJ, Reed CM, Fenton B, Okunieff $P$, Finkelstein JN: Effect of administration of lovastatin on the development of late pulmonary effects after whole-lung irradiation in a murine model. Radiat Res 2004, 161(5):560-567.

23. Monceau V, Pasinetti N, Schupp C, Pouzoulet F, Opolon P, Vozenin MC: Modulation of the Rho/ROCK pathway in heart and lung after thorax irradiation reveals targets to improve normal tissue toxicity. Curr Drug Targets 2010, 11(11):1395-1404.

24. Ikawa Y, Ng PS, Endo K, Kondo M, Chujo S, Ishida W, Shirasaki F, Fujimoto M, Takehara K: Neutralizing monoclonal antibody to human connective tissue growth factor ameliorates transforming growth factorbeta-induced mouse fibrosis. J Cell Physiol 2008, 216(3):680-687.

25. Abdollahi A, Li M, Ping G, Plathow C, Domhan S, Kiessling F, Lee LB, McMahon G, Grone HJ, Lipson KE, et al: Inhibition of platelet-derived growth factor signaling attenuates pulmonary fibrosis. J Exp Med 2005, 201(6):925-935.

26. Vuorinen K, Gao F, Oury TD, Kinnula VL, Myllarniemi M: Imatinib mesylate inhibits fibrogenesis in asbestos-induced interstitial pneumonia. Exp Lung Res 2007, 33(7):357-373.
27. Gordon JK, Spiera RF: Targeting tyrosine kinases: a novel therapeutic strategy for systemic sclerosis. Curr Opin Rheumatol 2010, 22(6):690-695.

28. Gaugler MH, Vereycken-Holler V, Squiban C, Vandamme M, VozeninBrotons MC, Benderitter M: Pravastatin limits endothelial activation after irradiation and decreases the resulting inflammatory and thrombotic responses. Radiat Res 2005, 163(5):479-487.

29. Noble PW, Albera C, Bradford WZ, Costabel U, Glassberg MK, Kardatzke D, King TE Jr, Lancaster L, Sahn SA, Szwarcberg J, et al: Pirfenidone in patients with idiopathic pulmonary fibrosis (CAPACITY): two randomised trials. Lancet 2011, 377(9779):1760-1769.

30. Richeldi L, Costabel U, Selman M, Kim DS, Hansell DM, Nicholson AG, Brown KK, Flaherty KR, Noble PW, Raghu G, et al: Efficacy of a tyrosine kinase inhibitor in idiopathic pulmonary fibrosis. N Engl J Med 2011, 365(12):1079-1087.

31. Delanian S, Balla-Mekias S, Lefaix JL: Striking regression of chronic radiotherapy damage in a clinical trial of combined pentoxifylline and tocopherol. J Clin Oncol 1999, 17(10):3283-3290.

32. Delanian S, Porcher R, Balla-Mekias S, Lefaix JL: Randomized, placebocontrolled trial of combined pentoxifylline and tocopherol for regression of superficial radiation-induced fibrosis. J Clin Oncol 2003, 21(13):2545-2550.

33. Delanian $\mathrm{S}$, Depondt J, Lefaix JL: Major healing of refractory mandible osteoradionecrosis after treatment combining pentoxifylline and tocopherol: a phase II trial. Head Neck 2005, 27(2):114-123.

34. Delanian S, Porcher R, Rudant J, Lefaix JL: Kinetics of response to longterm treatment combining pentoxifylline and tocopherol in patients with superficial radiation-induced fibrosis. J Clin Oncol 2005, 23(34):8570-8579.

35. Letur-Konirsch $\mathrm{H}$, Guis F, Delanian S: Uterine restoration by radiation sequelae regression with combined pentoxifylline-tocopherol: a phase II study. Fertil Steril 2002, 77(6):1219-1226.

36. Haddad P, Kalaghchi B, Amouzegar-Hashemi F: Pentoxifylline and vitamin E combination for superficial radiation-induced fibrosis: a phase II clinical trial. Radiother Oncol 2005, 77(3):324-326

37. Hille A, Christiansen H, Pradier O, Hermann RM, Siekmeyer B, Weiss E, Hilgers R, Hess CF, Schmidberger H: Effect of pentoxifylline and tocopherol on radiation proctitis/enteritis. Strahlenther Onkol 2005, 181(9):606-614.

38. Gothard L, Cornes P, Brooker S, Earl J, Glees J, Hall E, Peckitt C, Tait D, Yarnold J: Phase II study of vitamin $E$ and pentoxifylline in patients with late side effects of pelvic radiotherapy. Radiother Oncol 2005, 75(3):334-341.

39. Delanian S, Martin M, Bravard A, Luccioni C, Lefaix JL: Cu/Zn superoxide dismutase modulates phenotypic changes in cultured fibroblasts from human skin with chronic radiotherapy damage. Radiother Oncol 2001, 58(3):325-331.

40. Vozenin-Brotons MC, Sivan V, Gault N, Renard C, Geffrotin C, Delanian S, Lefaix JL, Martin M: Antifibrotic action of Cu/Zn SOD is mediated by TGFbeta1 repression and phenotypic reversion of myofibroblasts. Free Radic Biol Med 2001, 30(1):30-42.

41. Lefaix JL, Delanian S, Vozenin MC, Leplat JJ, Tricaud Y, Martin M: Striking regression of subcutaneous fibrosis induced by high doses of gamma rays using a combination of pentoxifylline and alpha-tocopherol: an experimental study. Int J Radiat Oncol Biol Phys 1999, 43(4):839-847.

42. Ledee-Bataille N, Olivennes F, Lefaix JL, Chaouat G, Frydman R, Delanian S: Combined treatment by pentoxifylline and tocopherol for recipient women with a thin endometrium enrolled in an oocyte donation programme. Hum Reprod 2002, 17(5):1249-1253.

43. Boerma M, Roberto KA, Hauer-Jensen M: Prevention and treatment of functional and structural radiation injury in the rat heart by pentoxifylline and alpha-tocopherol. Int I Radiat Oncol Biol Phys 2008, 72(1):170-177.

44. Delanian S, Chatel C, Porcher R, Depondt J, Lefaix JL: Complete restoration of refractory mandibular osteoradionecrosis by prolonged treatment with a pentoxifylline-tocopherol-clodronate combination (PENTOCLO): a phase II trial. Int J Radiat Oncol Biol Phys 2011, 80(3):832-839.

45. Delanian S, Lefaix JL, Maisonobe T, Salachas F, Pradat PF: Significant clinical improvement in radiation-induced lumbosacral polyradiculopathy by a treatment combining pentoxifylline, tocopherol, and clodronate (Pentoclo). J Neurol Sci 2008, 275(1-2):164-166. 
46. Azzi A, Gysin R, Kempna P, Munteanu A, Negis Y, Villacorta L, Visarius T, Zingg JM: Vitamin E mediates cell signaling and regulation of gene expression. Ann N Y Acad Sci 2004, 1031:86-95.

47. Ricciarelli R, Maroni P, Ozer N, Zingg JM, Azzi A: Age-dependent increase of collagenase expression can be reduced by alpha-tocopherol via protein kinase C inhibition. Free Radic Biol Med 1999, 27(7-8):729-737.

48. Akeson AL, Woods CW, Mosher LB, Thomas CE, Jackson RL: Inhibition of IL1 beta expression in THP-1 cells by probucol and tocopherol. Atherosclerosis 1991, 86(2-3):261-270.

49. Chojkier M, Houglum K, Lee KS, Buck M: Long- and short-term D-alphatocopherol supplementation inhibits liver collagen alpha1(I) gene expression. Am J Physiol 1998, 275(6 Pt 1):G1480-1485.

50. Devaraj S, Chan AV Jr, Jialal I: alpha-Tocopherol supplementation decreases plasminogen activator inhibitor-1 and P-selectin levels in type 2 diabetic patients. Diabetes Care 2002, 25(3):524-529.

51. Villacorta L, Graca-Souza AV, Ricciarelli R, Zingg JM, Azzi A: Alphatocopherol induces expression of connective tissue growth factor and antagonizes tumor necrosis factor-alpha-mediated downregulation in human smooth muscle cells. Circ Res 2003, 92(1):104-110.

52. Horvath B, Marton Z, Halmosi R, Alexy T, Szapary L, Vekasi J, Biro Z, Habon $T$, Kesmarky $G$, Toth $K$ : In vitro antioxidant properties of pentoxifylline, piracetam, and vinpocetine. Clin Neuropharmacol 2002, 25(1):37-42.

53. Berman B, Duncan MR: Pentoxifylline inhibits normal human dermal fibroblast in vitro proliferation, collagen, glycosaminoglycan, and fibronectin production, and increases collagenase activity. J Invest Dermatol 1989, 92(4):605-610.

54. Berman B, Duncan MR: Pentoxifylline inhibits the proliferation of human fibroblasts derived from keloid, scleroderma and morphoea skin and their production of collagen, glycosaminoglycans and fibronectin. $\mathrm{Br} J$ Dermatol 1990, 123(3):339-346.

55. Duncan MR, Hasan A, Berman B: Pentoxifylline, pentifylline, and interferons decrease type I and III procollagen mRNA levels in dermal fibroblasts: evidence for mediation by nuclear factor 1 down-regulation. $J$ Invest Dermatol 1995, 104(2):282-286.

56. Janknecht R, Wells NJ, Hunter T: TGF-beta-stimulated cooperation of smad proteins with the coactivators CBP/p300. Genes Dev 1998, 12(14):2114-2119.

57. Pouponnot C, Jayaraman L, Massague J: Physical and functional interaction of SMADs and p300/CBP. J Biol Chem 1998, 273(36):22865-22868

58. Schiller M, Verrecchia F, Mauviel A: Cyclic adenosine $3^{\prime}, 5^{\prime}$-monophosphateelevating agents inhibit transforming growth factor-beta-induced SMAD3/4-dependent transcription via a protein kinase A-dependent mechanism. Oncogene 2003, 22(55):8881-8890.

59. Laurent C, Pouget JP, Voisin P: Modulation of DNA damage by pentoxifylline and alpha-tocopherol in skin fibroblasts exposed to Gamma rays. Radiat Res 2005, 164(1):63-72.

doi:10.1186/1755-1536-5-S1-S13

Cite this article as: Hamama et al:: Therapeutic management of intestinal fibrosis induced by radiation therapy: from molecular profiling to new intervention strategies et vice et versa. Fibrogenesis \& Tissue Repair 2012 5(Suppl 1):S13.

\section{Submit your next manuscript to BioMed Central and take full advantage of:}

- Convenient online submission

- Thorough peer review

- No space constraints or color figure charges

- Immediate publication on acceptance

- Inclusion in PubMed, CAS, Scopus and Google Scholar

- Research which is freely available for redistribution 